\title{
SOME REFLECTIONS ON THE MUSCLE RELAXANTS, WITH SPECIAL REFERENCE TO DECAMETHONIUM*
}

\author{
GeOFFrey ORG.ANE, IM.D., F.F.A.R.C.S. *
}

MY REFLECTIONS on the muscle relaxants are provoked by the increase in their number and variety, in our detailed knowledge of their pharmacology, and in our experience of their use in clinical ana esthesia, since my first visit to Canada in 1949. True, it was already seven years since we had been scandalized by the first report from Griffith and Johnson (1) of the use of Intocostrin to produce muscle relaxation for surgical operations, but it was only three and a half years since Prescott (2) had become the first human being to be submitted to a paralysing dose of pure d-tubocurarme chloride, and little more than three years since Gray and Halton (3) had passed the milestone of their first thousand cases with Tubarine. The first clinical reports of gallamine (4) and decamethonium (5) had just been published; mephanesin, dimethyl tubocurarine, benzoquinone, laudexium, and the succinylcholines were still to come.

I can speak only from hearsay of recent pharmacological work, but: a brief review is necessary as some of it has a bearing on our use of these agents in clnical anaesthesia. There was a time when the situation seemed fairly clearthere were relaxants which acted by competition with acetylcholine and there were others which simulated its action, producing depolarization of the myoneural junction. It is now evident that this classification is no longer sufficient and that many relaxants combine, to some extent, both these properties.

D-tubocurarme still ranks as a pure compettion blocker of the myoneural junction (6) ("ant1-depolarızing" (7) or "non-depolarızing" (8) are, perhaps, more accurate descriptions), though it is of interest that its block of the action of acetylcholine at the autonomic ganglia is by depolarization, with initial stimulation. As might be expected, its use in clinical practice has changed little, though some anaesthetists now use doses that are generous to the point of extrevagance! D-tubocurarine releases histamine, and the fall in blood pressure that it induces in animals is said to be due to the histamine release, not to the ganglion block Blood pressure fall in human beings is so rare as to occasion some doubt as to the relationship, and most of us are inclined to think that the release has a stabilizing effect on the blood pressure curve, an impression which flatters our handling of the anaesthetic. The release of histamine, however, may play a part in the comparatively rare development of bronchospasm and of massive lung collapse. Some protection from this has been claimed for antihistaminics given beforehand but, as in the treatment of all rare complications, it is difficult to be certain of the value of any preventive measure.

It should be noted that the elimination of d-tubocurarme from the body is slow, taking more than twenty-four hours The rapid recovery from the effect of

'Presented at the Annual Meeting of the Canadian Anaesthetists' Society, Toronto, June 21, 1955

* Westminster Hospital, London, England 
a single dose is said to be due, as in the case of thiopentone, to its redistribution in the tissues. After doses repeated to a high total, with tissue saturation, recovery is disproportionally prolonged. Anti-cholinesterases will produce temporary improvement but some residual weakness must be expected for many hours. I can see no advantage in using a larger dose than the smallest that will allow the satisfactory performance of an operation and, to my mind, too few anaesthetists make use of the remarkable potentiating effects of small amounts of ether in securing additional relaxation for the concluding stages of an operation. Such effects pass off rapidly, and completely, as the ether is elıminated.

Gallamine needs no detalled mention. It is as active as d-tubocurarine in producing parasympathetic ganglion block (9) and histamine release (4), when given in doses of equivalent paralysing effect. The predominant vagolytic action has been cläimed as an advantage in preventing coughing durnng pneumolysis (10) but, because of the resultant tachycardra, is a disadvantage when induced hypotension is to be employed. It may be of value when the anaesthetist has forgotten to apply a topical anaesthetic before tracheal intubation.

Benzoquinone compares unfavourably with other relaxants but is of academic interest because of its intermediate position between those which produce paralysis in all animals, without initial stimulation, and those which act primarily by persistent depolarızation, producing convulsive rigıdıty in some. Its block, like that of d-tubocurarme, will reduce the effectiveness of decamethonium and is increased by ether, yet it has anti-cholmesterase activity and is accentuated by neostigmine and edrophonıum.

The first warning that the neuromuscular block produced by decamethonium was more complicated than had been thought came with reports of a curare-like block in some animals (11) and of the prolonged panalysis eventually produced in myasthenics (12), who were resistant to doses much above the normal. There were also the reduced effectiveness of successive doses and occasional unexplained cases of prolonged apnoea in apparently normal patients. A mixed depolarization and anti-depolarization block was postulated and is now generally accepted. The theories as to how this comes about are largely speculative and seem to me unnecessarily complicated However, it appears that:, with an active but transient depolarization block decamethonium produces a much less complete but more prolonged anti-depolarization block. With successive doses the anti-depolarization block becomes more complete. This, as in the case of d-tubocurarine, reduces the effectiveness of the depolarization block of subsequent doses (the so-called tachyphylaxis). Eventually the anti-depolarization block itself produces an effective paralysis with prolonged apnoea.

Many possible mechanisms have been put forward, with experimental support, to account for the occasional prolonged paralysis following suxamethoniumlowered plasma cholinesterase (13), carbon dioxide retention (14), accumulation of succinylmonocholine (15), and dual block. None of these is wholly satisfying as an explanation but any or all could play a part. Until the position is further clarified it must be assumed that, in those cases where anti-cholinesterases have produced an increase in muscle tone, an effective anti-depolarization block has been present. Apart from the obvious error of carbon dioxide accumulation, these 
are effects of a relative over-dose and can probably be avoided by following the fundamental principle of varying the dose to the needs of the individual satient (16). It seems unwise to complicate the issue by using suxamethonium w ien its effectiveness has alreeıdy been reduced by a previous injection of d-tubocurarine.

One of my objects is to give a brief account of the use of decamethonium in anaesthetic practice and to suggest that it has certain advantages because of which it might be more widely employed. Nearly as much decamethonium is used at Westminster Hospital as in the rest of Great Britain put together. The reason for its general unpopularity is the láck of an effective antidote. This reason has never impressed us. In general, we take the view that the correct dose of any agent is the smallest that will produce the required effect: and that any technique which includes the routine use of an antidote must be regarded with suspicion. Though we do not hesitate to use neostigmine or edrophonium when we consider it necessary, this necessity is unusual and we regard it as evidence of our misjudgment of the dose of relaxant.

Accordingly, we have persisted with decamethonium and we now have an experience of several thousand cases, extending over the last six years. It has been used for nearly all types of operation and a general pattern of the range of its usefulness has begun to emerge.

The initial dose ${ }_{\gamma}$ in adults, has varied from as little as $2 \mathrm{mgm}$. to as much as $12 \mathrm{mgm}$. A dose of $3 \mathrm{mgm}$. will often not produce adequate muscle relaxation for an upper abdominal operation, though it would be suitable for interval appendicectomy. I would use $3 \mathrm{mgm}$, too, for low segment Claesarian section where full muscle paralysis is not necessary and where, in spite of experimental evidence that decamethonium does not cross the placenta, I prefer not to run the risk of any muscle weakness in the child. Otherwise, I give $4 \mathrm{mgm}$. when the operation is expected to last not longer than 20 or 25 minutes, and $5 \mathrm{mgm}$. if it is to be half an hour or more. This dose usually produces apnoea, which is my aim for reasons I shall mention later. Respiration is controlled by hand and, at the first sign of spontaneous breathing, or if muscle relaxation becomes inadequate, a further dose of relaxant is given. When the operation appears to be nearing cor pletion, suxamethonium is the most satisfactory; otherwise 3 to $5 \mathrm{mgm}$. of decame honium is injected, according to the patient's reaction to the initial dose. Of suxamethonium, 10 to $20 \mathrm{mgm}$. is usually sufficient and can be repeated as required. Full relaxation with apnoea for as long as half an hour, in these circumstances, can usually be produced w.th a total dose of $60 \mathrm{mgm}$. or less.

One of the most attractive features of decamethonium is the very sharp end point. Provided a suitable period has elapsed since the previous injection, it may take as little as one minute from the first attempt at breathing to the establishment of what appears to be full respiratory muscular activity. Not only is there no need for ary antidote, but there is no anxiety that a combination of central respiratory cepression with residual muscular weakness, which is invariably present to a greater or less degree with d-tubocurarine, may lead to a gradually mounting asphyxia and eventual respiratory failure.

The rapid recovery of respiratory function after a suitable dose of decamethonium is in accord with what we know of the more rapid recovery of active 
muscle groups, compared with those that are inactive (12). Some, at least, of the abdominal muscles take part in the early respiratory movements and abdominal relaxation will pass off very soon after breathing has started. For this reason I produce apnoea by the mitial dose of relaxant and maintain it for as long as possible by controlled respiration. This can prolong the period of effective abdominal relaxation by 20 to 30 per cent; by this means reduction of the dose is possible and rapid recovery ensured, and I regard it as an essential feature of the technique. There is sometmes a generalized recovery of muscle tone in a patient who is still apnoeic, but this can usually be anticlpated and prevented if a careful watch is kept.

In a few cases there has been no sign of respiratory activity at the expected time, and there has been generalized flaccidity of muscles. I have not seen this after a single dose of decamethonium, but it has occurred after repeated doses, to a total in excess of $10 \mathrm{mgm}$., usually of the order of $20 \mathrm{mgm}$. We assume that this is due to an ant-depolarnzation block and, after a suitable interval for observation, we treat it with neostigmme or edrophonium. These have proved effective and we have not, so far, seen any evidence of recurarization when the effect of the anticholinesterase has worn off. These presumed mixed blocks have been seen, also, when suxamethonium has been used to extend the period of relaxation after large doses of decamethonium (17) and they have responded in the same way to anticholinesterases.

Although they have given us no anxiety, I feel that these situations are better avoided. I think that this can be done if the totcl dose of decamethonium is restricted to $10 \mathrm{mgm}$., and if suxamethonium is avolded after a total of $10 \mathrm{mgm}$ of decamethonum. This implies that its use should be confined to operations where the necessary period of muscle relaxation will certainly be less than one and a half hours.

If, after repeated injections, the effect of the decamethonium appears to be diminished it is probably justifiable, in the light of our present knowledge, to assume that a significant degree of ant-depolarization block has been established. In such a case it may be wiser to continue the relaxation by cautious injection of an anti-depolarızation blocker, such as gallamine, rather than a depolarizing agent. It may be that my suggested maximum dose of $10 \mathrm{mgm}$ of decamethonium is an unnecessary restriction, and that it would be a sufficient safeguard if tachyphylaxis were taxen as a sign of a developed mixed block.

Anaesthesia can be induced and maintamed with the agents of choice, except ether, which has proved unsatisfactory I have found cyclopropane the most effective, and its rapid elimnation assists in the recovery of function at the end of operation. Recently I have been using thiopentone followed by demerol and nitrous oxide in most cases, to see how far I can succeed in avoiding inflammable agents. In most cases this sequence serves well enough, and the patient very quickly recovers consciousness, but it seems more difficult to handle and lacks the flexibility of cyclopropane as the anaesthesiat cannot easily be deepened temporarily to cover a partal recovery of muscle tone.

Decamethonium is largely excreted unchanged in the urine and we have seen no unusual reactions which we could relate to any disease of the patient. It has 
the further advantage, as far as we can tell, of having no other significant pharmacological action than that of neuromuscular block, an advantage possessed by no other muscle relaxant and most nearly approached by suxamethonium. If I were to be restricted to the use of one relaxant for all purposes I would choose d-tubocurarine but, within the limits and for the purposes I have suggested, I prefer decamethonium. It is also much less expensive than anything elsel

\section{RÉSUMÉ}

Il y eût un temps où la pharmacologie des curarisants était assez simple. Il y avalt ceux qui agissaient par compétition avec l'acetyl choline et ceux qui simulant son action, dépolarisarent la jonction myoneurale. Aujourd'hui, il est évident que cette classification ne suffit plus et que plusieurs curarisants ont, jusqu’à un certain dégré, ces deux propriétés.

La d-tubocurarine est encore décrite comme un bloqueur par compétition de la jonction myoneurale bien qu'll est intéressant de noter que son action d'arrêt de l'effet de l'acétyl cholıné aux ganglons autonomiques se fait par dépolarisation. La d-tubocurarıne libère de l'histamine à qui l'on' attribue la chute de tension artérielle notée chez les animaux de laboratoire. Cependant, chez l'homme, une chute de tension artérielle est si rare que l'on peut doûter de cette relation. Le relâchment de l'histamine joue possiblement un rôle dans les cas peu fréquents de bronchospasme et d'atélectasie massive.

La Benzoquinone quorqu'elle se compare défavorablement aux autres curarisants est intéressante du point de vue académique en ce que son action, comme celle .de la d-tubocurarme, diminue l'efficacité du décaméthonium, est accrue par l'éther et cependant elle a une activité anticholinestérase que s'accentue avec la néostigmine et l'edrophonium.

Il est généralement admis aujourd'hui que le décaméthonium produit un effet mixte de dépolarisation et d'antidépolarisation. Quand on emploie des doses successives l'effet anti-dépolarisant devient plus complet et comme pour la d-tubocurarine, dımınue l'action dépolarisante Eventuellement l'effet anti-dépolarisant produit une paralysie efficace avec apnée prolongée. Celles-ci peuvent se traiter avec de la neostigmine ou de l'edrophonium après une période d'observation suffisante. Cet effet mixte a aussi été noté quand on emploie le suxaméthonium pour prolonger la période de relâchement après l'usage de doses importantes de décaméthonium.

L'auteur préfère employer le décaméthonium plutôf que d'autres cu arisants quand la durée de relấchment musculaire requis n'est pas plus d'une 'jeure et demie. La dose maximum doit être de préférence de $10 \mathrm{mgm}$. Si après injections répétées, l'effet du décaméthonium semble être diminué il est probablement justifiable de penser qu'une action anti-dépolarisante importante s'est établie et il peut être plus sage de continuer la curarisation en injectant prudemment un bloqueur de l'anti-dépolarisation comme la gallamine.

Le décaméthonium est excrété en grande partie comme tel dans les urines, n'a pas d'effet pharmacologique autre que de bloquer la jonction neuromusculaire et est beaucoup moins dispendieux que les autres curarisants. 


\section{REFERENCES}

1. Griffrrm, H. R. \& Johnson, G. E. The Use of Gurare in General Anaesthesia. Anesthesiology 3.418 (1942).

2. Prescott, F., Organe, G \& Rowbotham, S. Tubocurarine Chloride as an Adjunct to Anaesthesia. Lancet 1: 80 (1946).

3. Gray, T. C. \& Halton, J. A Milestone in Anaesthesia? (d-Tubocurarine Chlonde). Proc. Roy. Soc. Med. 39: 400 (1946)

4. Organe, G.' Decamethonum Iodide (Bistrumethylammonium Decane Duodide) in Anaesthesia. Lancet 1773 (1949).

Hewer, A. J. H., Lucas, B G B, Prescott, F. \& Rowbotham, E S Decamethomum Iodide as a Muscle Relaxant in Anaesthesia. Lancet 1. 81\% (1949).

5. Musimn, W. W., WiEN, R., Mason, D. F. J. \& Langston, G. T. Curare-like Actions of Tri(Diethylamınoethoxy) Benzene Triethiodide. Lancet 1: 727 (1949)

6. Hoppe, J. Q. Observations on the Potency of Neuromuscular Blocking Agents with particular reference to Succinylcholine. Anesthesiology 16. 11 (1955).

7. Foldes, F. F. The Mode of Action of Quaternary Ammonium type Neuromuscular, BlockIng Agents. Brit. J. Anaesth 26. 394 (1954)

8. Churchill-Davidson, H. C. Abnormal Response to Muscle Relaxants. Prbc Roy. Soc. Med. 48: 621 (1955)

9. Desmarez, J. J Comparative Effects of d-Tubocurarne and Flaxedil on the Sympathetic System. Compt. rend. Soc. de biol. 148722 (1954).

10. Ballantine, R. I. W. Anaesthesia for Thoracoplasty Anaesthesia 719 (1952).

11. Zarmis, E. J. Motor End-Plate Differences as a Determining Factor in the Mode of Action of Neuromuscular Blockang Substances. Nature 170617 (1952).

12. Churceinl-Davioson, H C. \& Richaroson, A. T Decamethonium Iodide (C10). Some Observations on its Action using Electromyography Proc. Roy. Soc. Med. 45179 (1952).

13. Evans, F. T., Gray, P., Lehman, H \& Silk, E. Effect of Pseudocholinesterase Level on Action of Succinylcholine in Man Brit. Med J 1. 136 ( 1953)

Borders, R. W, Stephien, C R, Nownl, W. K \& MArtin, R. The Interrelationship of Succinylcholne and the Blood Cholnesterases during Anesthesia. Anesthesiology 16: 401 (1955).

14. Davis, D. A., Eluss, F. C 4 , Reese, N O \& Grosskreutz, D C The Prolonged Effects of Succinylcholne and Some Possible Explanations for These Phenomena. Anesthesiology 16: 333 (1955).

Scurr, C. F. Carbon Dioxide Retention Simulating Curarization. Bnt Med J 1564 (1954).

15. Hall, L. W. \& LemmanN, H Response in Dogs to Relaxants derived from Succinic Acid with Choline Brit. Med. J. 1: 134 (1953).

Foldes, F. F. \& Rhodes, D. H., Jr. Role of Plasma Cholinesterase in Anesthesiology. Anesth. \& Analg. 32: 305 (1953)

16. Foldes, F. F., VAndervort, R. S. \& Shanor, S. P. The Fate of Succinylcholine in Man Anesthesiology 16: 11 (1955).

17. Scurr, C. F. Personal communication. 